\title{
Women of Haryana; a Necessary but Neglected \& Repressed, Part of Society: An Analysis
}

\author{
Balkar Singh \\ Ph.D. Researcher Scholar, Department of English, Starex University, Gurugram, India. \\ DOI: 10.29322/IJSRP.11.06.2021.p11450 \\ http://dx.doi.org/10.29322/IJSRP.11.06.2021.p11450
}

\begin{abstract}
Haryana is a prosperous state of India situated in north, has contributed in glorifying the name of nation by producing the Sports Persons \& youths of the state are dedicatedly joining the India Army for the Security of our country. 1st, 1966 was the day when it was formed on the basis of the language, out of the state of Punjab. It is including the oldest civilisations of the world, the Indus Valley Civilization found in village Rakhigarhi (Hisar) and Bhirrama in Faridabad district which are approximately more than 9000 years old and since the year 2005 we are listening \& watching through electronic media "No.1 Haryana". And the state Government has introduced number of schemes for the empowerment of women like; BETI PADHAO BETI BACHAO LADLI \& SABLE, etc since the past few year. This study/research will cover the scenario of real condition, Discrimination and Mental conditions of the Dalit women, \& Negligence of the duties by the responsible persons of the society towards these girls/women in Haryana:
\end{abstract}

Index Terms- Security of our country, empowerment of women, Discrimination.

\section{Points may be discussed in this study:}

* Violence during the life cycle of women; dowry, sexual harassment.

* Status of women.

* Crime against women.

* Liberty in making decision.

* Circumstances of getting Education for girls.

* Patriarchal customs of the society.

* Comparison of parental love, affections \& imparting opinion in decision of both daughter \& son.

- Impact: A different kind of generation, Irresponsible towards society, disinterestedness for Politics.

\section{Detailed Discussion}

\section{DPoint No. 1}

\section{Violence during the life cycle of women:}

There is a word 'life cycle' is mentioned above, the justification of this is that every girl/women have to pass through this series of actions to survive, some lost their lives at 1st stage, some reaches upto last stage i.e. old age. It can be understood by this example; if a girl child is survived \& got married when he got pregnant, she was brought to the Doctors not for medical or any health checkups but for determining the sex of the baby before its birth. If the report shows the boy it is good or if it shows a girl child, it leads to abortion. However, there are strict guidelines for the doctors for not determining the sex of the baby before birth, but due to corruption and in the motive of earning more and more money, these are declined.

Table A: Gender Violence during Life Circle

\begin{tabular}{|l|l|l|}
\hline $\begin{array}{l}\text { Sr. } \\
\text { No. }\end{array}$ & Stages & Form of Violence \\
\hline 1 & Pre-birth Stage & Female Foeticide \\
\hline 2 & Infancy Stage & $\begin{array}{l}\text { Female Infanticide and Gender } \\
\text { Discrimination. }\end{array}$ \\
\hline 3 & Childhood Stage & $\begin{array}{l}\text { Gender discrimination in the way } \\
\text { of Health, Food, Education, etc. }\end{array}$ \\
\hline 4 & Adolescent Stage & $\begin{array}{l}\text { At this stage; early marriage, rape, } \\
\text { dress code, restriction of use of } \\
\text { information technology, eve- } \\
\text { teasing etc., are faced. }\end{array}$ \\
\hline 5 & $\begin{array}{l}\text { Reproductive } \\
\text { Stage }\end{array}$ & $\begin{array}{l}\text { Domestic violence in the form of } \\
\text { marital rape, emotionally or } \\
\text { physically tortured by husband or } \\
\text { his family. }\end{array}$ \\
\hline 6 & Old Age & $\begin{array}{l}\text { At this stage generally faces abuse; } \\
\text { elderly or financial abuse. }\end{array}$ \\
\hline
\end{tabular}

\section{$>$ Dowry}

Apart from this at the time of marriage, the parents of a girl, being poor or rich, as per the custom of the society, have to give some households to their daughter since ancient times. At that time this was called 'DAHEJ', which was considered a sacred custom, as there was no pressure for the same on the parents of a girl, but in present time, this term 'DAHEJ' has been changed into 'Groom Price' of Dowry. In this system, after the marriage the bride is used to be exploited, subjected to cruelty, or harassed by her husband or any other relative of her husband for demanding cash, property, or any other means of wealth from her parents. Not doing so, she has to face 'Dowry Death'.

\section{$>$ Sexual Harassment}

As said in the below discussion, women are considered as property by men being dominant in the society, especially in Haryana. In the 21st century, women of India are educated and confident, who are building India; taking our country to newer heights of glory \& achievements. They are shining in every field of work women are shining. However, it is quite unfortunate that women at most of the workplaces are facing sexual harassment 
which is in substance an attack on their dignity. They are unable to get an environment which is free from sexual harassment and fear. Right to Life \& Right to Equality have been provided to us by the Constitution of India. Right to life includes the right to live with dignity, right to practice any profession, commerce and occupation also includes the right to have an environment free from sexual harassment. Sexual harassment of woman employee/worker at the workplace is an infringement of the constitutional rights, violation of the human rights $\&$ a form of discrimination in India. Due to sexual harassment woman, organization \& country as a whole suffers. According to a judgment of the Supreme Court, interpreted gender equality of women in relation to work, and exploitation of women in the way of sexual harassment at the workplace is clear violation of the their rights. Since the past time, the Hon'ble Supreme Court of India has laid down number of guidelines or direction for the prevention of women at workplace from sexual harassment. The court stated that these guidelines were to remain binding until suitable legislation was passed to deal with the issue. To monitor the cases of sexual harassment at work place, Sexual Harassment of Women at Workplace (Prevention, Prohibition and Redressal) Act, 2013 was passed by the Indian Parliament. This is very helpful in the urban areas, where the offices of Govt./Private sectors" are situated. But in the rural areas of villages in Haryana, these judgments/orders are useless, as women are considered honour $\&$ it is observed by the men that silent \& submissive kind of women is accepted by the society, as she is responsible of the family honour as a daughter, wife and mother while man control it. So, women of Haryana are helpless in that rural areas \& victimized in the name of honour, its result is that if a girl is raped/gang-raped, it is considered that she has brought shame to her family and community as well. And in this way she is stopped to file any complaint against the accused in any Police station or before any commission.

\section{Point No. 2 \\ Status of women:}

Haryana is the center of the Green revolution \& white revolution, being the center of these two revolutions, most of the farmers, keep animals like; buffalo, cows \&goats. Whenever, any of these is get pregnant, the owner of it thinks that there should be a she-calf or she-got as these are considered productive gadgets of the wealth. But, in the case of women, at the time of the birth of a baby, it is considered that there should be born a boy-child instead of a girl, so in this way, the status of women is differentiated from animals \& considered lower than of that. There are a few movies are produced in the Haryanvi language and in most of these movies, the main theme of violence was women \& even one was produced having the name: ZAR, ZORU AUR ZAMEEN, which means wealth, women \& land, respectively in English. So, in this way in the tradition of Haryana women are considered as equitant with wealth or land; property.

\section{Point No. 3}

\section{Crime against women:}

According to a report of Haryana State Commission for Women, published in the Times of India that during lockdown $78 \%$ rise in crimes against women in Haryana, as per data collated from across the districts by including the complaints made on the women's helpline number (1091), the women police stations and directly to HSCW. In modern times the ways \& forms of crimes have been changed. These days, if a girl gets educated and able to get any kind of employment in Government sectors, then it will be a difficult work for her parents to find a suitable boy for her marriage $\&$ if any educated boy was found, the marriage has taken place, the terminology of crime also starts taking place. I would like to explain this by an example: In November 2019 a girl, working as a Professor in a Government College in Panipat (Haryana) was married to a boy, working as a Post Graduate Teacher in a Government School at Kaithal (Haryana), all customs were done peacefully \& a lot of households were given by the parents of that girl. But, after passing more than two months, the boy started harassing her, by demanding more and money from her, he used to withdraw huge amounts from her SBI bank accounts by using ATM cards, without her knowing. Then he objected to her dressing styles, not attending the phone calls of her colleague, students, or any friends, he uses to check her mobile phones, Whatsapp accounts means he imposed restrictions on her like a slave, whereas she is highly educated and working as a Professor (class 1 Gazetted) \& blamed her as characterless; having pre-marriage affairs, without having any facts \& started to poke her publically. So, the lady had to leave his house and came to her parents with her small baby girl (born recently).

Table B: Types of Gender Violence in Haryana

\begin{tabular}{|l|l|l|}
\hline Crime & \multicolumn{2}{|l|}{} \\
\hline Sr. No. & Leading to Death & Not leading to death \\
\hline 1 & Abetment to suicide & Rape \\
\hline 2 & Murder & Molestation \\
\hline 3 & Culpable Homicide & Cruelty against women \\
\hline 4 & Dowry Deaths & Eve-teasing \\
\hline 5 & & Dowry Prohibition Act \\
6 & & Trafficking \\
& & Female Foeticide \\
\hline 7 & &
\end{tabular}

\section{Point No. 4}

\section{Liberty in making decision}

In the most of the places of Haryana, if a girl is born then she is subjected to different forms of violence like; lack of education, providing food, freedom, playing or speaking freely. On the other hand, huge pocket money is provided to her brother. But, in other cases, the parents are educated and educate their daughter in a local school, collages level, when she tries to decide her carrier and further education, she is stopped by either her parents or by the society of Haryana by saying "ladki ko jada sir pe nahi chadhaan chahiye", but if this stage is cleared by that girl, she is allowed with a number of restrictions. She can't make boys her friends, she can't go out with these friends, if she does so, and it results in leaving her education. A girl never can choose his life partner of her choice for getting marriage due to the dominance of the father figure in the family/society. A number of cases of honour killing are filed in Haryana, if a girl tries to marry a boy of her choice, as love-marriage is considered a crime in Haryana by Khaaps.

\section{Point No. 5}

Circumstances of getting Education for girls: 
Discussing this issue, the education policy of the family is set before the birth of a child, with planning that if a son will be born, he will be educated in this or that school, parents will make him a Doctor or Engineer or any Officer, all these things are decided before the birth of the child. After, the birth, if there is a son, all the planning are implemented and desires are tried to be fulfilled, but if unfortunately, there is a girl child, she is used to be neglected in all sphere of the life, it was not planned to educate her, to make her Doctor/Engineer/Officer. She used to push in the domestic works like; preparing food, cutting grass for animals, 'Silai-Kadhai' work, etc., but deprived of getting educated.

\section{Point No. 6}

\section{Sexual violence against Dalit women committed by dominant caste men:}

According to a report of the Swabhiman Society (organization headed by Dalit women)\&International Women's Rights Organisation Equality, published in 'Justice Denied: Sexual Violence and Intersectional Discrimination - Barriers to Accessing Justice for Dalit Women and Girls in Haryana' examined cases, occurred, from 2009 - 2020, approximately $80 \%$ violence cases in Haryana, against Dalit girls \& women were commonly committed by the people of dominant castes, but only $10 \%$ of cases examined ended with the successful conviction of all those charged. And it is a matter of fact that most of the convictions were obtained against all accused persons involved in either rape or murder were committed against girls under the age of 6 years old.

The report examined, that 40 numbers of girls and women, who were Dalit were raped over a span of 12 years, in Haryana, all these cases are from 11 districts of Haryana out of 22, like the above said organization, is working at grassroots in these eleven districts and further most cases of rape were held in Hisar, Kaithal, Sonipat \& Kurukshetra.

As per a talk held with a Dalit man of the nearby village of Karnal district, the main reason behind the sexual violence against Dalit Women/girls is that approximately all these kind of people don't have any kind of land, are not in good economic conditions and their daughter, women are not educated to perform any kind of office work, being the limited source of getting work, they have to work in the fields of the landlords/zamindaars of their villages. While working there, the owner of the land, not all but most of them, used to try to establish sexual relations with that repressed girls/women, when it doesn't happen easily then they raped them $\&$ being economically and politically in a sound position, they threaten the families of that girls/women for not complaining, if anyone or two of them tries to file any FIR of complaint, first of all the Police \& local administration of the State does not accept their complaints and if any complaint is registered, then the complainant or exploited person is murdered by the dominant persons of the society. The same thing happened $\&$ can be seen in the case of the raped girl; Manisha of Hathras.

\section{CONCLUSION}

No doubt, Haryana is economically ranking at 3rd position in India, it is the producer of the Green \& While revolutions, glorifying the name of the nation in Sports \&playing a big role for the Security of our country, all these achievements show the bright side of the Haryana State, but on the other hand the women; necessary part of the society is neglected, repressed and have the poor status. Girls have to suffer violence through their life circle from the stage of Pre-birth State to their old age. During her childhood she is often under-nourished, remains deprived of education, received injuries \& even murdered in their marital homes. To protect them from all this violence, many laws are framed in the Constitution of India like; Indian Penal Code (IPC), at Local level laws Immoral Traffic (Prevention) Act, 1956, Dowry Prohibition Act, 1961, Indecent Representation of Women (Prohibition) Act, 1986, Sati Prevention Act, 1987 \& Domestic Violence Act, 2005 \&Government has also taken a number of steps by launching initiatives like; BETI PADHAO BETI BACHAO LADLI \& SABLE, etc, since the past few years, but these schemes are not sufficient to protect the girls/women, there is a need of a change of mindset of the people $\&$ wee need to give more power to the women to empower them, so that they can become independent in taking decision. Further Government must impose all these Penal codes, Laws \& Schemes strictly so that the culprits should be punished.

\section{REFERENCES}

[1] https://indianexpress.com/article/cities/chandigarh/haryana-in-2-years-45jump-in-crimes-against-women-6210717/

[2] https://indianexpress.com/article/cities/chandigarh/haryana-cases-ofcruelty-against-women-up-17-27-in-2019-6285051/

[3] https://timesofindia.indiatimes.com/city/gurgaon/no-green-for-palwal-twofresh-cases-after-15-days/articleshow/75524278.cms

[4] Sexual Harassment at Workplace (Sexual Harassment of Women at Workplace Prevention, Prohibition and Redressal Act., 2013 \& Some provision of Indian Penal Code, 1860) Haryana State Legal Services Authority

\section{AUTHORS}

First Author - Balkar Singh, Ph.D. Researcher Scholar, Department of English, Starex University, Gurugram, India. Email: balkarsinghbidlan@gmail.com 